plastic materials (Fig. 1). Typical British household refuse now has a gross calorific value in the range 4,000-4 500 British Thermal Units per pound compared with 5,000 Btu per pound in the United States and 2,000 to 3,000 Btu per pound in Europe. But, although the calorific value of refuse seems bound to increase, the economies in scale in the generation of electricity with conventional fuels mean that generation from refuse is only worthwhile in plants on the scale of that being built at Edmonton. Interest in small scale generation from refuse is declining.

\section{MATHEMATICS TEACHING}

\section{The Point of No Return}

Forecasts made by the Institute of Mathematics and its Applications indicate that unless drastic steps are taken immediately, Britain's supply of mathematics school teachers will fall beyond a point of no return by 1970. Appeals for action made as long ago as 1961 by people like Professor Thwaites at the University of Southampton were ignored, but the vicious circle whereby fewer good teachers inspire fewer pupils to take up mathematics is continuing and the institute has now initiated discussions with the Department of Education and Science in an attempt to get the Government to take steps towards solving the problem. This is part of its widespread campaign to bring the problem, with some proposals the institute has worked out for its amelioration, to the notice of organizations and individuals in a position to help. It is hoped that discussions with the University Grants Committee will start soon.

The report issued after a meeting in February between Mrs Shirley Williams, the Minister of State for Education, and a delegation from the institute stresses the fact that although the Government has already taken some action-for example, influencing the university departments of education to increase the number of mathematics graduates taking postgraduate courses from 400 in 1968 to more than 500 in. 1969 - there is no room for complacency. About half the country's mathematical teaching in the first five secondary school years is undertaken by teachers with no mathematical qualifications (as compared with about one fifth in, for example, France) and despite the achievements of universities in doubling their output of mathematics graduates in the past seven years there has been little increase in the number of graduates going into teaching.

The principal recommendations made by the institute were that the UGC should initiate a study of how the numerical balance between the subject groupings for the period 1972 to 1977 could be adjusted to meet the need for mathematics teachers, and, sccondly, that there should be an increase in the number of places in mathematics education courses offered by universitics, polytechnics and teachers training colleges. Mrs Williams agreed that something will have to be done soon, but reminded the delegation that it was a difficult time to find money for new developments and also that the idea of earmarking money for particular university purposes was a controversial subject. She said that experimental three-year degree courses in mathematics and education had already been started at some universities and that the Council for
National Academic Awards had been discussing the idea of courses which included an education element. Another of the institute's ideas which received support was that university students might be organized to stand in during the months of June and July for teachers who would then be free to go on refresher courses for teaching mathematics.

\section{EDUCATION \\ Nulfield in Universities}

THE Nuffield Foundation is continuing the good work of encouraging new teaching methods, but moving from the schools to the universities. It has just given $£ 80,000$ to the Universities of Bath, Birmingham, Glasgow, London and Sussex to produce some new teaching material, involving a certain amount of self instruction, to lighten the load of biology teachers.

Three types of course are to be prepared: bridge courses intended to fill awkward gaps in the knowledge of school leavers; technique courses, to teach particular skills such as bacterial culture; and so-called main courses for insertion into existing university courses. These categories reflect some of the current problems facing biology departments which prompted several universities to express an interest in the development of new techniques. Heads of departments were worried about the heterogeneous nature of their intake, increasingly including students who have not studied. biology at school, and about the amount of time wasted in repetitive teaching of simple techniques. Departments also tend to suffer from an inadequacy in their teaching force-if a department has no mycologist, for example, how does it teach mycology?

The five universities which finally became involved in the scheme, under the chairmanship of Professor O. E. Lowenstein, all have on their staff, as well as biologists, experts in educational techniques. Birmingham, for example, has the National Centre for Programmed Learning, Glasgow has a television unit and Sussex has a centre for educational technology. Members of these units, working with the biologists, will start next October to produce the first drafts. Each university will work on particular courses, making use of its own special expertise. Sussex, for example, will produce bridge courses for first year students in. developmental biology and cell biology, and Birming. ham will produce a course on aseptic techniques. London, represented by Queen Elizabeth College and Chelsea College of Science and Technology, will be working on a course on enzyme metabolism, to be incorporated into ordinary university biology courses.

Film loops, colour sides with accompanying tapes and programmed material are all likely to be uscd in the courses, which will be designed to last ten to fifteen hours and to include contact with teachers in the form of, for example, tutorials, as well as self instruction. The authors of this project are not aiming to replace the teachers, but to reduce the demand on them in some areas, so that more personal attention can be given in others.

After the courses have been tricd out, and probably revised, by the university that produces them, they will be tried by the other four, and any other universities that express an interest. After further revision, by about 1972, they should be ready for publication. 